\title{
Financial Performance of Master Plan Landscape Architects Pvt Ltd, Chennai
}

\author{
Magdalene Peter, S.Fabiyola Kavitha, J.Pavithra
}

\begin{abstract}
In the present cash related world, budgetary execution is a necessities among the perspective of various accomplices, be it in the organization, banks, owners and theorists' perspective. Moreover, it is out of examination of monetary reports. Budgetary execution is critical for taking fiscal decisions related to organizing and control. Thusly, it shapes the reason as one of the importance for taking budgetary decisions effectively. Banking Sector expect a huge activity in money related improvement of a country. The budgetary course of action of India is incorporated by a huge arrangement of bank workplaces, serving various sorts of fiscal organizations of the people Axis Bank today is a primary player in Indian money related industry and is significantly busy with human and financial improvement at the national level. The Bank works personally with in spite of the way that it is private. bank ascended as a pioneer experience not very far away of offering an all-encompassing extent of banking things and cash related organizations for corporate and retail customers through its different movement redirects and packed assistants in the districts of theory banking, asset the officials, subsidizing and insurance. In the light of its key criticalness in the nation premium, it is crucial to evaluate the cash related execution of the Axis Bank. Likewise, the present examination focused on operational control of the bit of leeway, profit and dissolvability, etc.
\end{abstract}

Keywords : performance analysis,landscape,masterplan

\section{INTRODUCTION}

The level of execution of a business over a predefined time span, imparted similarly as overall advantages and adversities during that time. Evaluating the budgetary introduction of a business grants pioneers to condemn the delayed consequences of business systems and activities in objective financial terms. [1],[3],[5]

Budgetary execution insinuates the showing of performing cash related activity. In increasingly broad sense, fiscal execution suggests how a lot of cash related goals being or has been rehearsed. It is the path toward assessing the eventual outcomes of an affiliation's approaches and undertakings in monetary terms. It is used to measure organization's all things considered budgetary prosperity over a given time allotment and can in like manner be used to

Revised Manuscript Received on July 22, 2019.

Magdalene Peter, Department of MBA, Bharath Institute of Higher Education and Research, Tamilnadu, India. Email: magdalene.bsb@gmail.com

Fabiyola Kavitha, Department of MBA, Bharath Institute of Higher Education and Research, Tamilnadu, India. Email: fabiyolakavitha@gmail.com

J.Pavithra, Department of MBA, Bharath Institute of Higher Education and Research, Tamilnadu, India Email: pavithralect@yahoo.com consider near firms over a comparative industry or to take a gander at ventures or fragments in accumulation. [2 ],[4],[6]

\section{A. BREAKING DOWN 'Financial Performance}

There are a wide extent of approaches to manage assess budgetary execution, yet all measures ought to be taken in get-together. Nuances, for example, pay from endeavors, working pay or pay from activities can be utilized, comparably as complete unit deals. Also, the analyst or scholar may wish to look further into money related reports and search out edge progression rates or any declining responsibility. [7],[9] ,[11]

There are a wide extent of accessories in an affiliation, including exchange leasers, budgetary authorities, analysts, specialists and the executives. Every social event has its very own vitality for following the budgetary presentation of an affiliation. Analysts find a few solutions concerning monetary execution from information appropriated by the relationship in Form $10 \mathrm{~K}$, for the most part called the yearly report. The $10 \mathrm{~K}$ is a required complete account that must be passed on by every single open affiliation. The clarification behind the report is to give assistants exact and dependable spending reports that give a graph of the affiliation's money related execution. Also, these revelations are examined and set apart by the association of the affiliation adjacent distinctive other presentation records. Consequently, the $10 \mathrm{~K}$ tends to the most intensive wellspring of data on budgetary execution made open for scholars on a yearly reason. Included inside the $10 \mathrm{~K}$ are three spending outlines, the bit of leeway report, the pay revelation and the compensation clarification. [8],[ 10], [12]

\section{OBJECTIVES}

\section{A.PRIMARY OBJECTIVE}

To analyse the financial performance of the master plan landscape architects private ltd

\section{B.SECONDARY OBJECTIVE}

- To compare last five years of financial performance of the company

- To know the financial growth of the company

- To study the strength and weakness of the firm

- To provide useful suggestions to improve the financial performance of the company

\section{RESEARCH DESIGN}

This study is a descriptive Research. Data pertaining behaviour of liquidity solvency and profitability position were collection from the balance sheet 
and profit \& loss account of master plan landscapes[13], [15] ,[17]

\section{A. SOURCES OF DATA}

The information was collected through secondary data which includes balance sheet and statement of profit and loss for last three years of the company[14],[16], [18]

\section{DATA ANALYSIS AND INTERPRETATION}

\section{RATIO ANALYSIS}

Table 1 CURRENT RATIO

\begin{tabular}{|l|l|l|l|}
\hline & & & \\
particulars & 2014 & 2015 & 2016 \\
\hline & & & \\
Current ratio & 1.54 & 0.24 & 2.92 \\
\hline
\end{tabular}

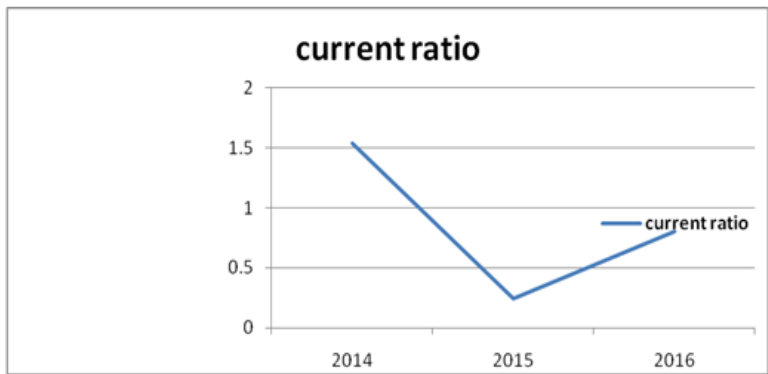

Fig:1 Current Ratio

\section{INFERENCE}

Current proportion is a liquidity proportion that estimates an organization's capacity to pay present moment and long haul commitments. This table demonstrates the present proportions in the year 2014 to 2016. In the year 2014, the present proportion was 1.54 and in the year 2015, it diminishes to 0.24 which shows absence of effective stock administration and increments to 2.92 in 2016 which means the organization utilizes its present resources productively in 2016[20],[22], [24]

\section{Table 2 QUICK RATIO}

\begin{tabular}{|c|c|c|c|}
\hline \begin{tabular}{|l} 
Particulars \\
\end{tabular} & 2014 & 2015 & 2016 \\
\hline Quick ratio & 0.16 & 0.04 & 0.80 \\
\hline
\end{tabular}

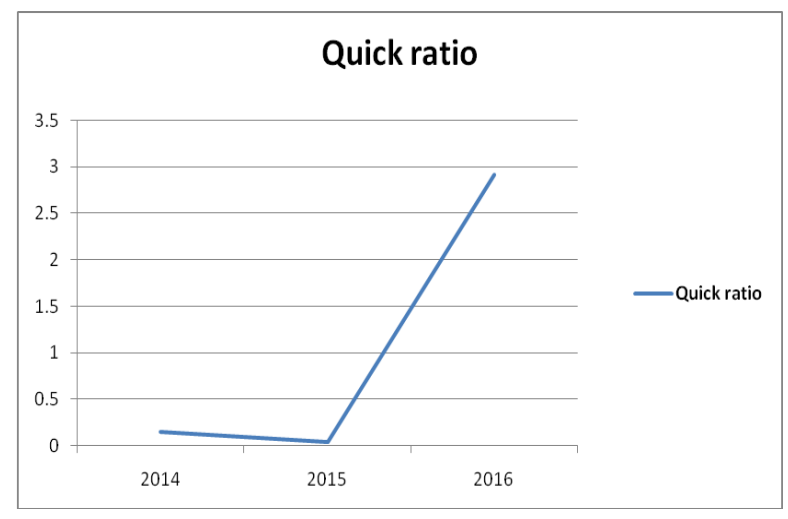

Fig:2 Quick Ratio

\section{INFERENCE}

Snappy proportion estimates the capacities of an organization to handle its momentary liabilities when it due with just speedy resources. This table demonstrates the present proportions in the year 2014 to 2016 . In the year 2014, snappy proportion was 0.16 and diminishes in 2015 and increments in 2016 to 0.80 . This demonstrates the organization don't keep up adequate and normal shorter advantages for pay off its momentary bills and this will influence its productivity. The organization need to lessen current liabilities increment current resources[19],[21],[23]

Table:3 RETURN ON AVERAGE ASSETS

\begin{tabular}{|l|l|l|l|}
\hline particulars & 2014 & 2015 & 2016 \\
& & & \\
\hline Return on average asset & $5.96 \%$ & $6.85 \%$ & $5.39 \%$ \\
& & & \\
\hline
\end{tabular}

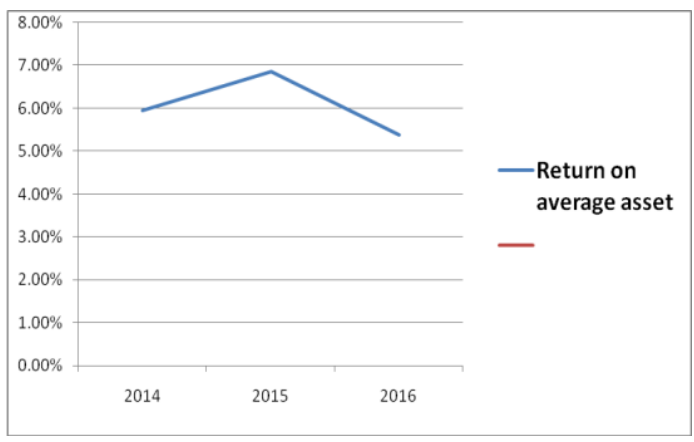

Fig:3 Return on average assests

\section{INFERENCE}

Profit for normal resource a marker used to get to the benefit of an association's advantages. This table demonstrates the present proportions in the year 2014 to 2016. In the year 2014 , the arrival all things considered resources was 5.96\%, in 2015 , the arrival by and large resources increments to $6.85 \%$ however in 2016 , it diminishes to $5.39 \%$. The shows that the organization return on resources isn't steady[25],[27],[29] 
Table:4 RETURN ON AVERAGE EQUITY
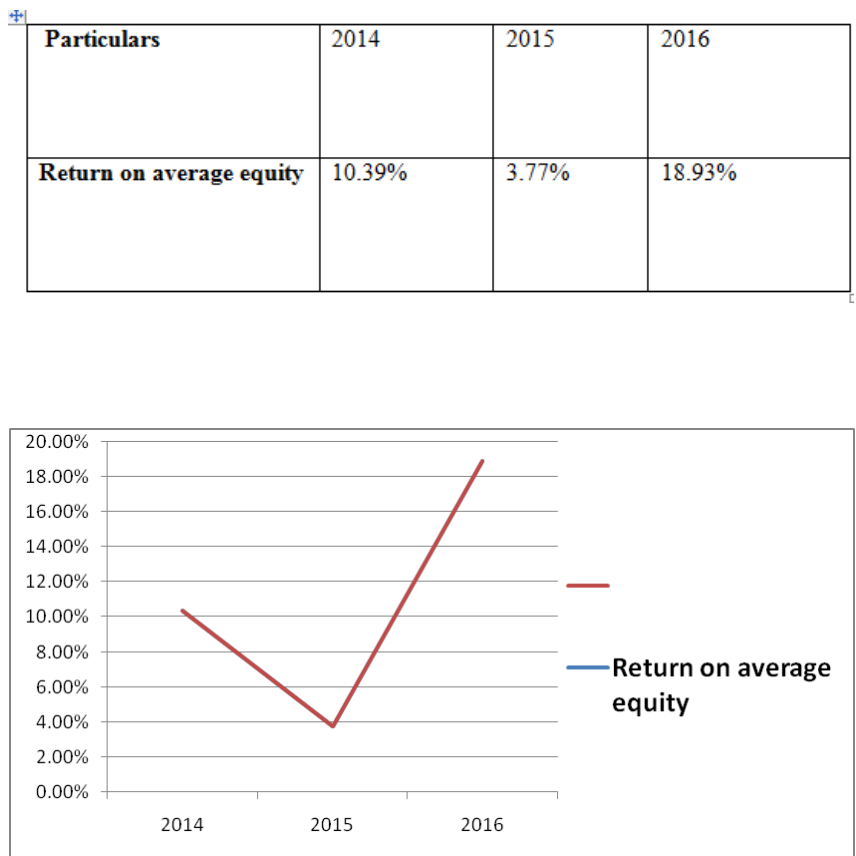

Fig:4 Return On Average Equity

\section{INFERENCE}

Profit for normal value estimates the capacity of a firm to produce benefits from its investors interests in the organization; this table demonstrates the Return by and large value in the year 2014 to 2016 . In the year 2014, return on value was $10.39 \%$, it radically diminished to $3.77 \%$ in the year 2015 and get in a quick rate to $18.93 \%$ in 2016 , and this shows the organization return on investors' value was great in 2016 and poor in 2015[31],[33],[32]

\section{Table:5 FIXED /WORTH RATIO}
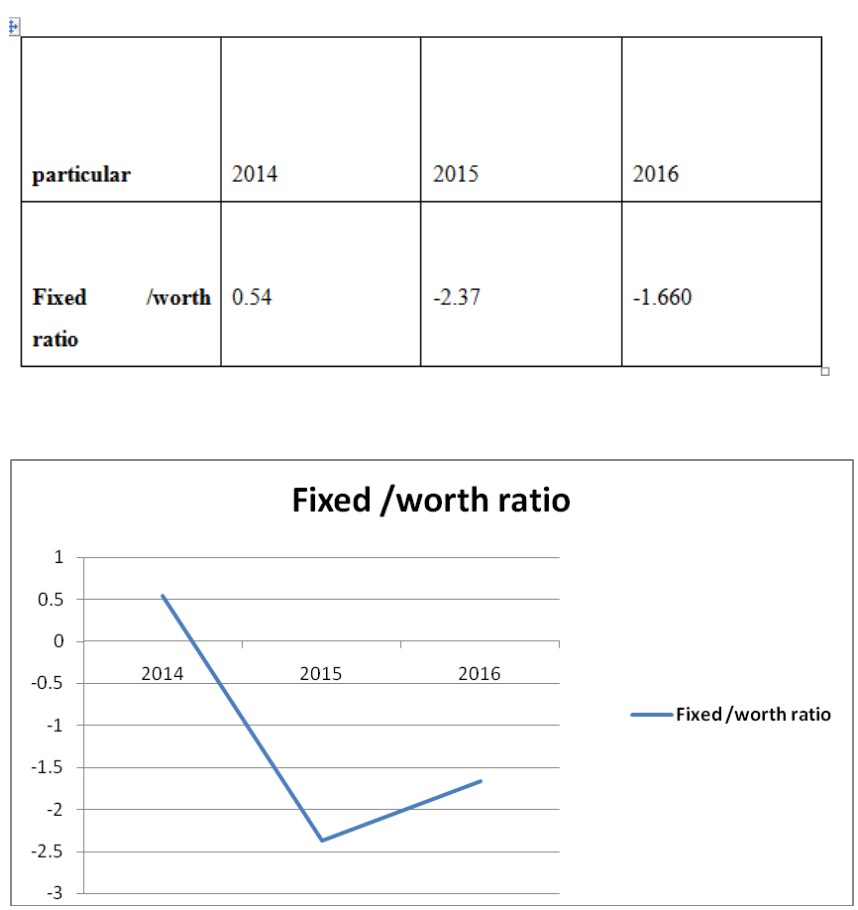

Fig:5 Fixed/Worth Ratio

\section{INFERENCE}

Fixed/worth shows how well the organization is utilizing its fixed advantages for create deals. This table demonstrates the fixed proportion of the organization beginning from 2014 to 2016. In 2014 the fixed proportion was 0.54 , in 2016 the fixed proportion ended up negative (-2.37) and furthermore negative in 2016 (-1.66). This demonstrates the organization has not been using it fixed resources in adequately. [26],[28],[30]

\section{Table:6 Operating Profit To Working Funds}
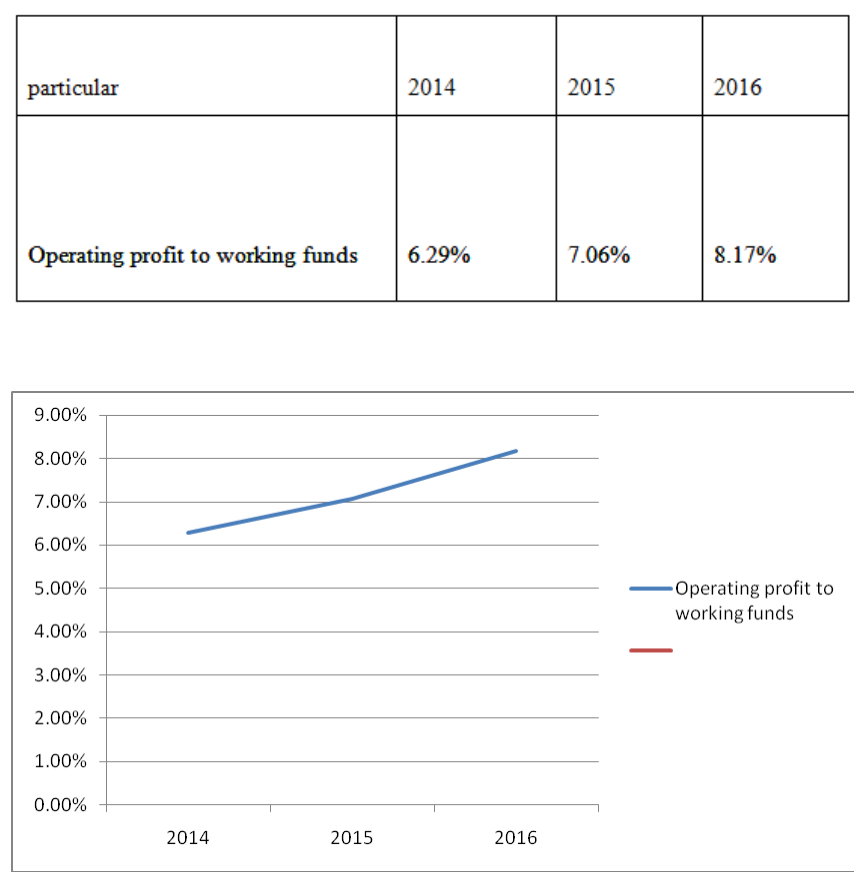

Fig:6 Operating Profit To Working Funds

\section{INFERENCE:}

Working benefit to working supports demonstrates the connection between the activity benefit and working assets. This table demonstrates the working benefit to working capital from 2014 to 2016. In 2014, the working benefit to working assets was $3.29 \%$ and it expanded a bit to $7.06 \%$ in the year 2015 and furthermore increments to $8.17 \%$ in the year 2016. This demonstrates the organization are using its working asset adequately and effectively

Table:7 Fixed Assets Ratio

\begin{tabular}{|l|l|l|l|}
\hline Particulars & 2014 & 2015 & 2016 \\
\hline & & & \\
fixed asset ratio & 0.51 & 2.09 & \\
\hline
\end{tabular}




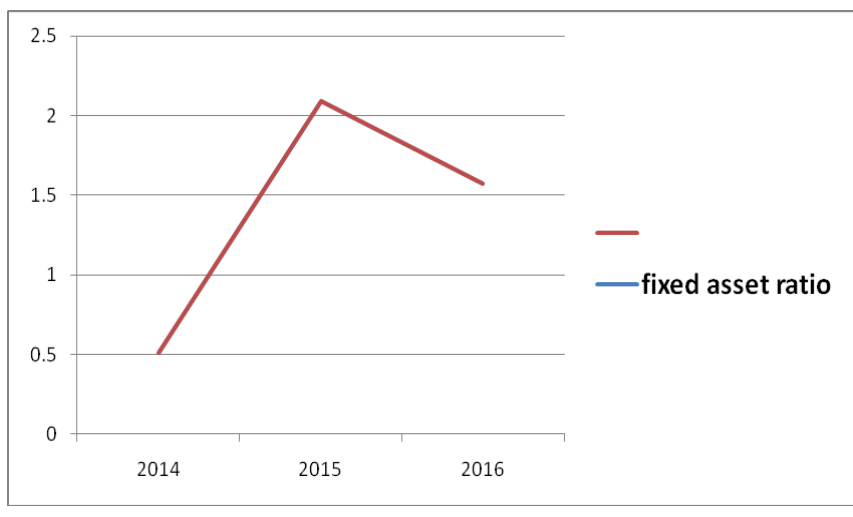

Fig:7 Fixed Assets Ratio

\section{INFERENCE}

Fixed resource proportion shows how well the business is utilizing its fixed advantages for create deals. This table demonstrates the fixed resource proportion from 2014 to 2016. In 2014 the fixed resource proportion was 0.51 , in the 2015, fixed resource proportion was 2.09 which is an expansion and in the year 2016, the fixed resource proportion diminished to 1.57. This demonstrate a misfortune in the administration of fixed resource

\section{Table:8 Proprietary Ratio}

\begin{tabular}{|l|l|l|l|}
\hline Particulars & 2014 & 2015 & 2016 \\
\hline $\begin{array}{l}\text { proprietary ratio/ equity } \\
\text { ratio }\end{array}$ & 0.57 & 0.41 & 0.29 \\
\hline
\end{tabular}

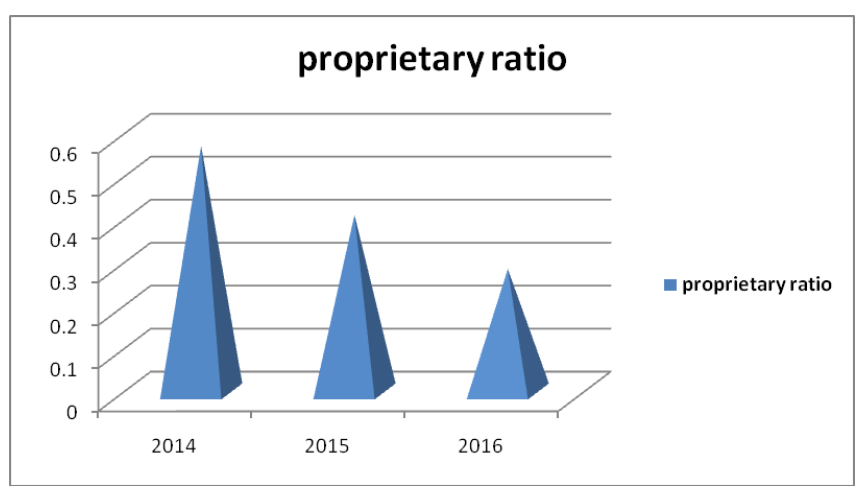

Fig:8 Proprietary Ratio

\section{INFERENCE}

Proprietary ratio is the proportion of shareholder's equity to the total assets. This table shows the equity ratio from 2014 to 2016. In 2014 equity ratio was 0.57 , while in 2015 the equity ratio decreased to 0.41 and decreased more to 0.29 in the year 2016
Table:9 CASH RATIO

\begin{tabular}{|l|l|l|l|}
\hline Particular & 2014 & 2015 & 2016 \\
\hline & & & \\
& & & \\
Cash ratio & 0.10 & 0.04 & 2.82 \\
\hline
\end{tabular}

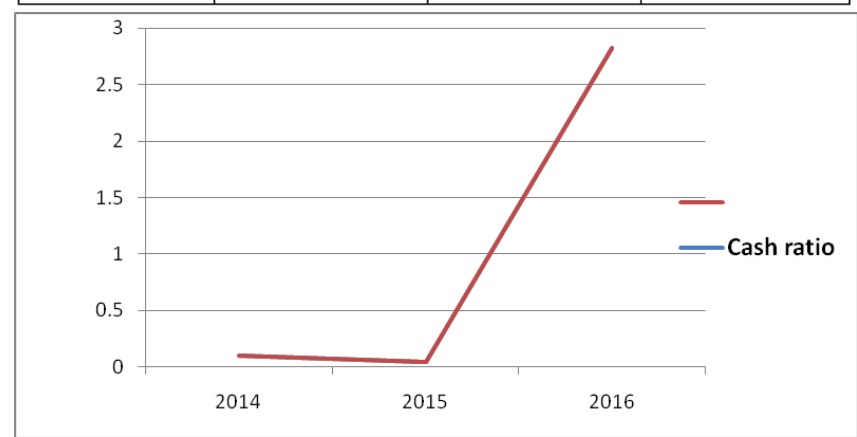

Fig:9 CASH RATIO

\section{INFERENCE:}

Cash ratio is the ability of a company to cover its liabilities than many other liquidity ratios. This table shows the cash ratio from 2014 to 2016 , in 2014 the cash ratio was 0.10 while in 2015 the cash ratio was 0.04 and it increases to 2.82 in the year 2016. This indicates that there is a growth in the cash available to pay off the company liabilities

Table:10 Expenses Ratio

\begin{tabular}{|l|l|l|l|}
\hline Particular & 2014 & 2015 & 2016 \\
\hline Expenses ratio & 0.98 & 1.00 & 0.95 \\
& & & \\
\hline
\end{tabular}

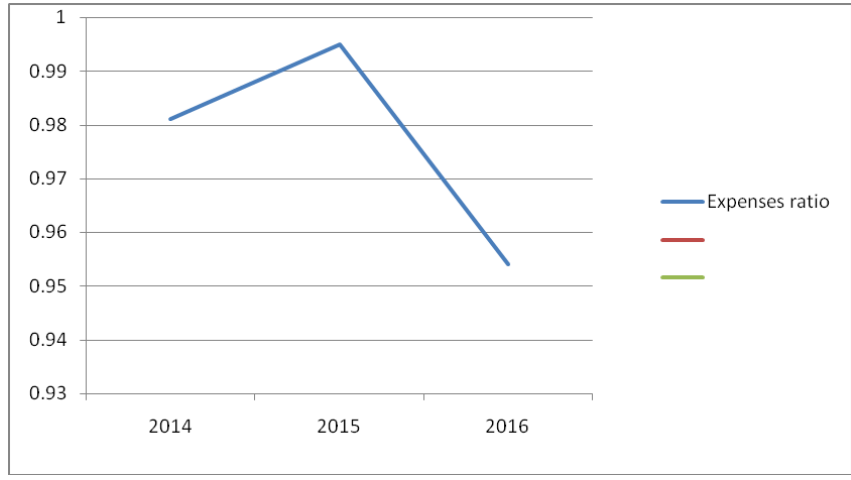

Fig:10 Expenses Ratio

\section{INFERENCE:}

Expenses ratio indicates the relationship of various expenses to net sales. This table above shows the expenses ratio from 32014 to 2016 . In the year 2014 the expenses ratio was 0.98 and it came up to 1.00 in the year 2015 and in 2016 the expenses ratio remain 0.95 . This is not much increment in the expenses of the company 


\section{V.RESULTS}

- The current proportion in the year 2014 was 1.54 and after that diminishes to 0.24 in the year 2015 and it again increments to 2.92 in the year 2016. This demonstrates the organization began getting a charge out of credit value in 2016

- The fast proportion in the year 2014 was 0.16 and diminishes to 0.04 in the year 2015 and later came up a bit to 0.80 in the year 2016

- The by and large monetary position of the organization in the year 2015 was not unreasonably great since, there was much variance in the complete presentation of the organization in the 2015

- The organization execution continue fluctuating thus the development isn't persistent in every one of the years

- The general set back the organization is confronting is absence of the executives and absence of customary venture from the customers

- Regarding the arrival on resource, in 2014 it was $5.96 \%$ and expanded to $6.85 \%$ which is great and dropped down to $5.39 \%$ in 2016 . The arrival on the benefit is great and furthermore a pointer that the advantages are utilized effectively particularly in the year 2015

- Return by and large value for the investor increments to $18.93 \%$ in the year 2016 and that is just year it return is high

- The consumption has consistently expanded distinctive extent from 2014 to 2016

- The figures of other salary has radically diminished during the time from 100 in the year 2014, dropped to 46.30 in 2015 and diminished more in 2016 to 39.73 which isn't acceptable

\section{DISCUSSION}

- The organization should limited its use in order to make more benefit particularly of administrative work

- The fixed resources ought to be all the more effectively utilized and not to be kept inactive whenever

- The the board ought to improve in their administration methods to guarantee in proficiency profitability

- Engage more in getting venture for the organization

- The firm ought to get more altruism from their customers to get more ventures for the organization
- The organization ought to get advertisers to land more position for the organization since the more the undertaking, the more the benefit for the organization

- More supervision from the administration side to screen the work toward utilizing the papers and different materials so as to maintain a strategic distance from wastage in the assets of the organization and buy of the materials for work

- More quality administrations ought to be rendered to their customers to guarantee great notoriety for the organization

- More compelling using of its benefits and investor's assets

- $\quad$ More Proper book of record ought to be keep up

\section{CONCLUSION}

The investigation uncovers that the generally speaking budgetary execution of the organization is reasonable. The organization has been keeping up great money related execution yet not every one of the years and the organization can further improve in the event that it amasses more in getting more activities and decreasing the uses both in the organization and different costs. The organization had the option to meet its investor return in 2016 which is great. When all is said in done detect, the general organization execution isn't steady during the time under investigation, along these lines the organization to place exertion in the efficiency to cause the money related execution to be persistently solid, to increment in increasingly nonstop benefit and ceaseless development in budgetary position of the organization

\section{REFERENCES}

1. G BharthVajan R., Ramachandran S.,Psychographic dimensions of training,2016,International Journal of Pharmacy and Technology,V-8,I-4,P-23727-23729

2. Balakrishnan P., Bharthvajan R.,A study on human resource planning in hospitals in Chennai City,2014,International Journal of Applied Engineering Research,V-9,I-22,P-7503-7507

3. Priyadarsini P., Bharthvajan R.,Role of emotional intelligence training programme in reducing the stress of the nurses,2014,International Journal of Applied Engineering Research,V-9,I-22,P-7411-7421

4. Kerinab Beenu G., Bharthvajan R.,Empirical analysis on the cosmetic buying behavior of young women in South India,2014,International Journal of Applied Engineering Research,V-9,I-22,P-7361-7366

5. Balakrishnan P., Bharthvajan R.,Whistling in the wind,2014,International Journal of Applied Engineering Research,V-9,I-22,P-7586-7593

6. Krishnan B., Peter M.,Health hazards of Indian Bpo employee-an alarming issue,2014,International Journal of Applied Engineering Research,V-9,I-22,P-7336-7341

7. Kerinab Beenu G.H., Peter M.,Role of insurance in economic development,2014,International Journal of Applied Engineering Research,V-9,I-22,P-7532-7539

8. Balakrishnan P., Peter M., Priyadarsini P.,Efficiency of safety measures for wellbeing of employees in manufacturing industry,2014,Internationa Journal of Applied Engineering Research,V-9,I-22,P-7376-7382

9. Anbarasi M., Praveen Kumar S.,Online sales promotions of herbal products and its effectiveness towards tanisha.com,2019,Indian Journal of Public Health Research and Development,V-10,I-1,P-195-200

10. Anbarasi M., Praveen Kumar S.,Various online marketing and promotions strategies to improve the validation towards the organic products in the pharmaceutical 
sectors,2019,Indian Journal of Public Health Research and Development,V-10,I-1,P-263-269

11. Loganathan R., Praveen Kumar S.,Grievance handling a key factor for solving issues of employees in an organization,2014,International Journal of Applied Engineering Research,V-9,I-22,P-7483-7491

12. Loganathan R., Praveen Kumar S.,Study on preference of private label brands in super and Hypermarkets,2014,International Journal of Applied Engineering Research,V-9,I-22,P-7327-7335

13. Smitha M., Praveen Kumar S.,Understanding stress and its managementamong the nurses in Chennai city,2014,International Journal of Applied Engineering Research,V-9,I-22,P-7560-7565

14. Kerinab Beenu G.H., Praveen Kumar S.,A study on the investment behavior of Chennai investors in mutual fund schemes, 2014,International Journal of Applied Engineering Research,V-9,I-22,P-7520-7525

15. Loganathan R., Praveen Kumar S.,Retention strategies key for organizational productivity,2014,International Journal of Applied Engineering Research,V-9,I-22,P-7443-7447

16. Pavithra J., Ganesan M., Brindha G.,State wise analysis of microfinance sector in India,2016,International Journal of Pharmacy and Technology,V-8,I-4,P-23417-23432

17. Pavithra J., Ganesan M.,A comparative study on microfinance in India and abroad,2016,International Journal of Applied Business and Economic Research,V-14,I-8,P-5471-5476

18. Pavithra J., Ganesan M.,A study on awareness and impact of micro-financial schemes,2016,International Journal of Applied Business and Economic Research,V-14,I-8,P-5449-5460

19. Senthilmurugan P., Pavithra J.,Consumer preference towards organised retailing with reference to Big Bazaar,2014,International Journal of Applied Engineering Research,V-9,I-22,P-7469-7475

20. Senthilmurugan P., Pavithra J.,Implication of social media marketing in growing healthcare industry,2014,International Journal of Applied Engineering Research,V-9,I-22,P-7448-7456

21. Loganathan R., Pavithra J.,Consumer perception towards private label brand over other brands in super markets and hypermarkets,2014,International Journal of Applied Engineering Research,V-9,I-22,P-7355-7360

22. Kerinab Beenu G., Pavithra J.,Tradeâ€"off between liquidity and profitability in logistics industry,2014,International Journal of Applied Engineering Research,V-9,I-22,P-7398-7401

23. Kerinab Beenu G., Pavithra J.,A study on the prospective consumerâ€TM perception towards utility cars in Chennai city,2014,International Journal of Applied Engineering Research,V-9,I-22,P-7526-7531

24. Pavithra J., Dilli Babu P., Ambuli T.V.,A study on budgetary control at Maruti Service Masters, Chennai,2014,International Journal of Applied Business and Economic Research,V-12,I-2,P-151-161

25. Pavithra J., Dilli Babu P., Ambuli T.V.,A study on customer satisfaction of retro Garments Pvt Ltd, Chennai,2014,International Journal of Applied Business and Economic Research,V-12,I-2,P-381-391

26. Kerinab Beenu G.H., Pavithra J., Senthilmurugan P.,A study on the influence of promotional activities for TATA ARIA among consumers in Chennai,2014,International Journal of Applied Engineering Research,V-9,I-22,P-7572-7578

27. Vijayaragavan S.P.,An investigative expert that's general FBG sensors, International Journal of Mechanical Engineering and Technology,V-8,I-8,PP-1500-1505,Y-2017

28. Vijayaragavan S.P.,Equalization routing protocol for $\mathrm{Wi}-\mathrm{Fi}$ sensor strategy,International Journal of Mechanical Engineering and Technology,V-8,I-8,PP-1662-1666,Y-2017

29. Karthik B., Kiran Kumar T.V.U., Vijayaragavan P., Bharath Kumaran E.,Design of a digital PLL using 0.35 $\hat{\mathrm{I}}^{1 / 4 \mathrm{~m}}$ CMOS technology,Middle East Journal of Scientific Research,V-18,I-12,PP-1803-1806,Y-2013

30. Kanniga E., Selvaramarathnam K., Sundararajan M.,Kandigital bike operating system,Middle - East Journal of Scientific Research, V

31. Jasmin M., Vigneshwaran T., Beulah Hemalatha S.,Design of power aware on chip embedded memory based FSM encoding in FPGA,International Journal of Applied Engineering Research,V-10,I-2,PP-4487-4496,Y-2015

32. Jasmin M.,Optimization techniques for low power VLSI circuits,Middle East Journal of Scientific Research,V-20,I-9,PP-1082-1087,Y-2014

33. Jasmin M., Vigneswaran T.,Fuzzy controller for error control of on - Chip communication,2017 International Conference on Algorithms, Methodology, Models and Applications in Emerging Technologies, ICAMMAET 2017,V-2017-January,I-,PP-1-5,Y-2017

\section{AUTHORS PROFILE}

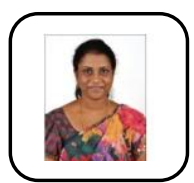

Magdalene Peter Assistant Professor, Department of MBA, Bharath Institute of Higher Education and Research, Tamilnadu, India.

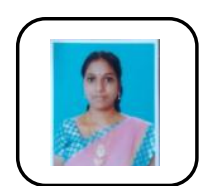

Fabiyola Kavitha Associate Professor, Department of MBA, Bharath Institute of Higher Education and Research, Tamilnadu, India.

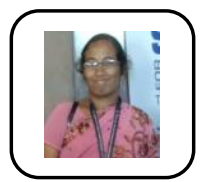

J.Pavithra Assistant Professor, Department of MBA, Bharath Institute of Higher Education and Research, Tamilnadu, India 